Sebastian KUBAS

DOI : 10.14746/pp.2017.22.1.10

Katowice

\title{
Zmiany w prawie wyborczym w kontekście przeobrażeń ustrojowych na Węgrzech po 2011 roku
}

\begin{abstract}
Streszczenie: Artykuł podejmuje problematykę zmiany prawa na Wegrzech po 2010 roku w aspekcie przeobrażeń konstytucyjnych oraz prawa wyborczego. Pierwsza część artykułu wiąże się z analizą zmian, jakie wprowadziła konstytucja Węgier w 2011 roku, zwana tam Fundamentalnym Prawem. Autor przedstawia i omawia sposób przygotowania i uchwalenia konstytucji przez posłów dominującej partii Fidesz oraz nowe podstawy ustrojowe i charakter podziału władzy. Druga część odnosi się do analizy trybu i efektów całkowitego przeobrażenia systemu wyborczego po 2011 roku, który zastąpił prawo wyborcze uchwalone jeszcze w 1990 roku. Nowe prawo wyborcze opiera się na trzech aktach przygotowanych i przegłosowanych większością głosów przez deputowanych z partii Fidesz. Aktami tymi są konstytucja, ustawa o wyborze posłów do parlamentu z 2011 roku i ustawa o procedurze wyborczej z 2013 roku.
\end{abstract}

Slowa kluczowe: Węgry, konstytucja, prawo wyborcze

z miany w węgierskim prawie wyborczym, które powstały w wyniku przejęcia władzy przez partię Fidesz - Węgierska Unia Obywatelska (węg. Fidesz - Magyar Polgári Szövetség) po wyborach parlamentarnych w 2010 roku i jej utrzymaniu w 2014 roku są jednym z elementów szerszych przekształceń zasad funkcjonowania podstawowych płaszczyzn życia publicznego w tym kraju. Celem artykułu jest analiza nowego systemu wyborczego ukazana na tle nowych zasad ustrojowych na Węgrzech. Podstawowe zasady ustrojowe wprowadziła konstytucja uchwalona w 2011 roku (zwana na Wegrzech Fundamentalnym Prawem), stwarzając tym samym ogólne ramy do dalszego zmieniania prawa regulującego instytucjonalne formy życia publicznego na Węgrzech. Pytanie, na które stara się odpowiedzieć autor brzmi: czy zmiany systemu wyborczego w świetle innych zmian prawnych na Węgrzech służą wzmocnieniu pozycji partii Fidesz, czy są pomyślane, jako przekształcenia modernizacyjno-cywilizacyjne współczesnego państwa demokratycznego?

Węgierski system wyborczy pozostawał niemal niezmienny od czasu rozpoczęcia przemian w 1989 roku. Wówczas powstał jako efekt negocjacji prowadzonych w ramach trójkątnego stołu, w którym rządząca elita władzy porozumiała się z opozycją. Wprowadzono do niego trzy poziomy repartycji mandatów, łącząc segment większościowy $\mathrm{z}$ okreggami jednomandatowymi (176 deputowanych), proporcjonalny z wielomandatowymi okręgami (152) oraz kompensacyjny z jednym ogólnokrajowym okręgiem wyborczym (58). W segmencie proporcjonalnym używano metody Hagenbacha-Bischoffa, a w kompensacyjnym d'Hondta. Jednakże ten mieszany system w rzeczywistości okazał się na tyle złożony, że był zrozumiały wyłącznie dla wytrawnych znawców problematyki (Sokół, 2007, s. 452-481). Tak skonstruowany system wyborczy przyczynił się do powstania i stabilizacji dwupartyjnego systemu, w którym o zwycięstwo w wyborach 
parlamentarnych ubiegały się prawicowy: Fidesz oraz lewicowa Węgierska Partia Socjalistyczna (węg. Magyar Szocialista Párt, MSzP).

Zmiany węgierskiego systemu wyborczego po 2010 roku udowadniają tezę przedstawioną przez Andrzeja Stelmacha o niedokończonym procesie zmian systemów wyborczych w państwach Europy Środkowej i Wschodniej. Andrzej Stelmach wskazuje na cztery fazy kształtowania się systemów wyborczych w naszej części Europy. Pierwsza faza, zwana rewolucyjna, ma gwałtowny ilościowy i jakościowy charakter, gdyż wprowadza nowe rozwiązania pozostające w opozycji do zasad poprzedniego reżimu. Druga faza to poszukiwania. Ma ona miejsce, gdy po wygaśnięciu euforii związanej ze zmianą reżimu, zaczyna się wprowadzać zmiany w prawie wyborczym, ale nadal o charakterze doraźnym. W trzeciej fazie korekty przyjmuje się pragmatyczne rozwiązania, które mają służyć interesom partii rządzących. Czwarta faza zwana jest stabilizacją i pojawia się, gdy doraźne interesy nie przeważają nad stabilnością prawa wyborczego i gdy nie dokonuje się zmian w zależności od potrzeby chwili ${ }^{1}$.

\section{Konstytucja z 2011 roku oraz jej nowelizacje}

Do 2011 roku Węgry były jedynym państwem w Europie Środkowej i Wschodniej, którego podstawy prawne wyznaczała konstytucja uchwalona w socjalizmie, co prawda wielokrotnie nowelizowana. Po wygranych wyborach parlamentarnych w 2010 roku Fidesz postanowił wykorzystać stan posiadania 2/3 mandatów w Zgromadzeniu Krajowym i uchwalił konstytucję opierającą się na założeniach ideowych tego prawicowego ugrupowania. Utworzona w 2010 roku koalicja rządowa Fidesz z Chrześcijańsko-Demokratyczną Partią Ludową (węg. Kereszténydemokrata Néppárt, KDNP) tuż przed uchwaleniem nowej konstytucji dokonała dziesięciokrotnej nowelizacji konstytucji z 1949 roku, przygotowując w ten sposób podłoże pod nowe, bardziej gruntowne zmiany ustrojowe. Osobą odpowiedzialną za koordynowanie prac nad projektem konstytucji był poseł Fidesz do Parlamentu Europejskiego József Szájer, który stanął także na czele Gremium Konsultacyjnego (Czyż, Kubas, 2011, s. 93). W związku z trybem prac nad konstytucją pojawiły się na Węgrzech i poza nimi słowa krytyki. Przede wszystkim wątpliwości budził fakt samego trybu prac nad konstytucją. Została ona przygotowana i uchwalona w trybie tzw. ustawy prywatnej. Oznaczało to, że zapisy ustawy CXXXI z 2010 roku o udziale społeczeństwa obywatelskiego w tworzeniu prawa, a także dekretu 24/2011 (VIII. 9.) Ministra Administracji Publicznej i Sprawiedliwości w sprawie wstępnej oceny skutków ex post nie miały tutaj zastosowania. Wydaje się, że konstytucja powinna być wprowadzana drogą ustawy rządowej, która wymaga szerokich, wielostronnych i długich debat z zainteresowanymi stronami. Konsultacje społeczne miały miejsce, ale ich charakter był bardzo ogólny i jednostronny. Na oficjalnej stronie internetowej Fidesz wskazano dwanaście spraw, które poddano dyskusji, a potem do prawie 8 milionów obywateli dotarły wstępne projekty założeń konstytucyjnych, z czego niecały milion ode-

${ }^{1}$ Koncepcja przedstawiona przez prof. Andrzeja Stelmacha w referacie „Kierunki zmian systemów wyborczych w państwach Europy Środkowo-Wschodniej” wygłoszonym w trakcie konferencji Ewolucja systemu politycznego w nowych państwach członkowskich Unii Europejskiej, Uniwersytet im. Adama Mickiewicza w Poznaniu, Słubice 15.05.2013. 
słano do Gremium Konsultacyjnego. Dnia 14 marca 2010 roku przedstawiono projekt konstytucji w parlamencie, a 25 kwietnia konstytucja została uchwalona 262 głosami za (Fidesz i KDNP) oraz 44 przeciwko (Jobbik). Weggierska Partia Socjalistyczna oraz partia Polityka Może Być Inna (węg. Lehet Más a Politika, LMP) zbojkotowały posiedzenie, na którym przyjmowano nową konstytucję. 25 kwietnia prezydent Pál Schmitt podpisał konstytucję, która weszła w życie 1 stycznia 2012 roku.

Pod względem formalnym konstytucja składa się z preambuły zwanej Narodowym Wyznaniem Wiary oraz pięciu rozdziałów zatytułowanych: Fundamenty, Wolność i Odpowiedzialność, Państwo, Szczególny reżim prawny oraz Przepisy końcowe. Preambuła rozpoczyna się od słów hymnu węgierskiego „Boże zbaw Węgrów”, co wzmacnia narodowo-konserwatywny charakter państwa, ponadto zmienia nazwę państwa z Republiki Węgierskiej na Węgry, odwołuje się do średniowiecznej idei korony św. Stefana, jako gwaranta ochrony tożsamości narodowej Węrów. Preambuła podkreśla znaczenie wartości chrześcijańskich, które pomogły w przetrwaniu narodu. W związku z wprowadzeniem zasady jednolitego narodu węgierskiego władze krajowe mają ponosić odpowiedzialność za sytuację Węgrów mieszkających poza granicami, pomagać w utrwalaniu i rozwoju więzi „zachowania węgierskości” oraz gwarantować wzajemną współpracę i współdziałanie z macierzą. Zniesiono obowiązek uzależniający korzystanie z praw wyborczych od zameldowania na Węgrzech. Twórcy konstytucji uznają brak przedawnienia w stosunku do zbrodni komunistycznych i to, że konstytucja z 1949 roku była i jest nieważna. Jednocześnie zauważają kryzys moralny XX wieku i w związku z tym wskazują na konieczność duchowej i intelektualnej odnowy.

Konstytucja nie zmienia zasadniczo formy państwa. Nadal mamy do czynienia z trójpodziałem władzy. Władzę sprawuje naród, który co cztery lata wybiera swoich przedstawicieli do Zgromadzenia Krajowego. Konstytucja normuje charakter Zgromadzenia Krajowego w artykułach 1-8. Legislacja pozostaje jego główną funkcją. Inicjatywę ustawodawczą posiadają: rząd, poszczególni deputowani, komisje, prezydent. Projekty ustaw kieruje się do przewodniczącego Zgromadzenia, który przesyła je do właściwej komisji. Projekt rozpatruje się w dwóch czytaniach. Po uchwaleniu ustawy podpisuje ją przewodniczący w przeciagu 15 dni i przesyła prezydentowi do 5 dni. Głowa państwa posiada prawo weta, zgodnie z którym może ustawę skierować do Trybunału Konstytucyjnego. Jeżeli TK nie potwierdzi wątpliwości prezydenta, ten musi ją niezwłocznie podpisać. Poza tym parlamentowi przypisano podstawowe funkcje znane w ustrojach demokratycznych, do których należą: ustrojodawcza, kreacyjna oraz kontrolna. W związku z tym Zgromadzenie Krajowe może wprowadzać nowe zasady ustrojowe, dokonuje wyboru prezydenta oraz ważnych funkcjonariuszy państwowych, a także sprawuje kontrolę nad działalnością rządu. W uzasadnionych przypadkach parlament może być rozwiązany przez prezydenta (Czyż, 2012, s. 127-147).

Poza organami władzy ustawodawczej konstytucja reguluje także zakres działalności organów władzy wykonawczej (prezydent: art. 9-14, rząd: art. 15-22) oraz sądowniczej (art. 25-28). Władzę wykonawczą sprawuje rząd, który składa się z premiera i ministrów. Premiera wskazuje Zgromadzeniu Krajowemu prezydent po zakończeniu wyborów parlamentarnych. Następnie na wniosek premiera pozostałych członków gabinetu powołuje prezydent. Kandydat na premiera przedstawia w parlamencie program rządu, który powinien zostać zaakceptowany przez większość deputowanych. Następnie otrzy- 
muje wotum zaufania, ale jeżeli kandydat na premiera nie otrzyma poparcia w parlamencie w terminie 40 dni od wskazania jego kandydatury przez prezydenta, to prezydent może rozwiązać parlament. Za swoją działalność rząd ponosi odpowiedzialność przed parlamentem. Zakończenie prac rządu może nastąpić np. w wyniku konstruktywnego wotum nieufności, a także zwykłego wotum nieufności w stosunku do premiera. Premier może wystapić o wotum zaufania wiążąc je z projektem ustawy. Jeżeli go nie otrzyma, musi podać rząd do dymisji. Do podstawowych zadań rządu należy kierowanie polityką krajowa, w tym administracją publiczną i polityką zagraniczna. Kadencja prezydenta trwa pięć lat z możliwością jednej reelekcji. Prezydentem może zostać Węgier, który ma prawa wyborcze i ukończył 35 lat. Kandydatów na prezydenta może zgłosić 50 deputowanych (jeden popiera tylko jednego kandydata). Przewodniczący Zgromadzenia zarządza przeprowadzenie wyborów. Wybór prezydenta powinien odbyć się w przeciagu dwóch następujących po sobie dni, w trakcie których mogą się odbyć dwie tury wyborów. W pierwszej turze prezydentem zostaje kandydat, który uzyska poparcie 2/3 wszystkich deputowanych. Jeżeli nie uda się w ten sposób wyłonić prezydenta, to w drugiej turze uczestniczy dwóch kandydatów z największą liczbą głosów z pierwszej tury. W drugiej turze prezydentem zostaje ten, który otrzyma większość głosów bez względu na liczbę głosujących deputowanych (Ustawa Zasadnicza Weggier z 25 kwietnia 2011 r.).

Konstytucja z 2011 roku nie określa struktury sądownictwa, pozostawia tę sprawę do uregulowania nowej ustawie. Stwierdza jedynie, że najwyższym organem sądownictwa jest Sąd Najwyższy (Kúria). Z prawnopolitycznego punktu widzenia, istotnym ciałem sądowniczym jest Trybunał Konstytucyjny (art. 24 konstytucji). Nowa ustawa zasadnicza z 2011 roku ograniczyła jego kompetencje i zmieniła strukturę. Powiększona została liczba sędziów z 11 do 15, a kadencję sędziów przedłużono z 9 do 12 lat. Konstytucja określa także zadania Rzecznika Praw Podstawowych, samorząa terytorialnego, wojska, policji, służby bezpieczeństwa (Kubas, 2012, s. 209-214). Na uwagę zasługuje fakt wskazania przez twórców konstytucji w jej pierwotnym tekście 26 zagadnień (obecnie 33), które mogą być uchwalane większością $2 / 3$ głosów m.in.: zasady systemu podatkowego i emerytalnego, polityka rodzinna, sądownictwo, prawa narodowości.

Uchwalenie konstytucji wywołało krajową oraz zagraniczną krytykę. Zarzucono przeforsowanie w nowej konstytucji ograniczenia roli Trybunału Konstytucyjnego. Zwiększono liczbę jego sędziów z 11 do 15, co pozwoliło na dodatkowy wybór 4 nowych sędziów przez parlamentarzystów kadencji Zgromadzenia Krajowego 2010-2014. Przewodniczącego TK nie wybierają, jak dawniej jego sędziowie, ale parlamentarzyści. Poza tym w kwestiach budżetowych TK ma uprawnienia do badania prawomocności ustawy w sytuacji, gdy dług publiczny wzrośnie powyżej konstytucyjnego limitu 50\% PKB. Zlikwidowano możliwość składania skarg do TK przez każdego obywatela (Act CLI of 2011). W związku z trudną sytuacją finansowo-ekonomiczną państwa, wzmocniono pozycję Rady Budżetowej, przyznając jej prawo zawetowania ustawy budżetowej. Rada jest wybierana na okres sześciu lat, co zapewnia większy wpływ na sprawy gospodarcze kraju Fideszowi. Co ciekawe, w konstytucji znajduje się przepis, że walutą narodowa jest forint, co w przyszłości utrudni przyjęcie euro.

Sposób uchwalenia konstytucji oraz jej regulacje prawne zostały skrytykowane przez Komisję Wenecką Rady Europy, a także inne instytucje zajmujące się kontrolowaniem przestrzegania procedur demokratycznych. Komisja Wenecka wielokrotnie zajmowała 
negatywne stanowisko zarówno w okresie przygotowawczym, jak i po uchwaleniu konstytucji. Od 2011 roku kilkadziesiąt razy wydawała opinie w sprawie węgierskiego prawa za każdym razem wskazując na brak przestrzegania procedur demokratycznych oraz negatywne konsekwencje dla systemu społecznego, politycznego i prawnego (Council of Europe). Również przedstawiciele różnych instytucji Unii Europejskiej apelowali do władz węgierskich o liberalizację uchwalanych przepisów. Przewodniczący Komisji Europejskiej José Manuel Barroso i Jean-Claude Juncker kilkakrotnie zabierali głos w tej sprawie i osobiście rozmawiali z premierem Węgier. Freedom House zwraca natomiast uwagę na ograniczenie praw obywateli w dostępie do Trybunału Konstytucyjnego, zwiększenie realnej władzy rządu przy ograniczeniu roli społeczeństwa obywatelskiego, uważa za szkodliwe ograniczenie władzy samorządu terytorialnego nad mieniem znajdującym się na terenie wspólnot samorządowych i przekazanie go państwu, likwidację urzędu Rzecznika Praw Obywatelskich i inne (Nations in Transit: Hungary).

Krajowa krytyka oprócz wymiaru społecznego przyjęła także formę instytucjonalną. W tym zakresie należy wskazać na kilkukrotne oświadczenia Trybunału Konstytucyjnego. Na przykład wątpliwości TK budził fakt przekroczenia uprawnień przez parlament w chwili przyjmowania przepisów przejściowych związanych z nową konstytucją Wskazano, że z technicznego punktu widzenia nie mają charakteru przejściowego (The Constitutional Court of Hungary, Decision 45/2012). W następstwie toczącego się przez wiele miesięcy procesu TK ostatecznie uchylił wiele postanowień przejściowych uchwalonych pod koniec grudnia 2012 roku, m.in. postanowienia dotyczące uprawnień Przewodniczącego Krajowego Biura Sądownictwa oraz Prokuratora Generalnego do wyznaczenia sądu innego niż sąd posiadający ogólną właściwość na rzecz rozstrzygnięcia sprawy w uzasadnionym terminie, postanowienie dotyczące mianowania Przewodniczącego Rady Budżetowej, uprawnienie parlamentu do wskazywania uznawanych kościołów oraz określania kryteriów uznawania innych kościołów, postanowienia dotyczące wyborów do samorządów terytorialnych i rejestracji wyborców, postanowienie dotyczące ustanowienia dnia 25 kwietnia „dniem ustawy zasadniczej” oraz uznania Węgierskiej Partii Socjalistycznej za organizację przestępczą i spadkobierczynię zbrodniczego reżimu komunistycznego (Dokument Roboczy nr 4, 2012, s. 5, 6).

Do dzisiaj koalicja Fidesz oraz KDNP pięciokrotnie nowelizowała konstytucję. Pierwsza zmiana związana była $\mathrm{z}$ wyjaśnieniem statusu prawnego postanowień przejściowych, które zanegował TK. W pierwszej zmianie z 4 czerwca 2012 roku uznano, że postanowienia przejściowe dotyczące ustawy zasadniczej stanowią de facto jej część. Ponadto pierwsza zmiana osłabiała niezależność Narodowego Banku Węgier, wprowadzała możliwość wpływania na jego decyzje przez inną instytucję państwową oraz nakazywała uchwalenie zmian w poborach byłych prezydentów większością 2/3 głosów parlamentarzystów. 29 października 2012 roku uchwalono drugą zmianę w konstytucji, która dotyczyła wymogu rejestracji w celu skorzystania z prawa do głosowania podczas wyborów parlamentarnych. Trzecia zmiana ogranicza wolność użytkowania, sprzedaży i nabywania ziemi węgierskiej i wymaga $2 / 3$ głosów deputowanych przy wprowadzaniu jakichkolwiek zmian $\mathrm{w}$ istniejącym prawie obrotu ziemią. Niewątpliwie najwięcej krytyki pojawiło się przy uchwaleniu czwartej zmiany w konstytucji. 
W tej zmianie zawarto niemal wszystkie postanowienia przejściowe, które uchylił Trybunał Konstytucyjny 28 grudnia 2012 roku. I tak uznano brak przedawnienia dla przestępstw popełnionych w okresie reżimu socjalistycznego, uprawniono parlament do sporządzania wykazu oficjalnie uznawanych kościołów i do ustalania szczegółowych zasad dotyczących praw grup narodowych, upoważniono Przewodniczącego Krajowego Biura Sądownictwa do wyznaczania sądów innych niż właściwy sąd powszechny do rozpoznawania spraw. Postanowiono, że z wolności wypowiedzi nie wolno korzystać w celu naruszenia godności narodu węgierskiego, absolwenci uczelni dotowanych przez państwo mogą być prawnie zobowiązani do świadczenia pracy na Węgrzech przez określony czas oraz to, że na mocy ustawy parlamentu lub lokalnego rozporządzenia można uznać za niezgodne z prawem przebywanie w miejscu publicznym służącym jako stałe miejsce zamieszkania. Czwarta zmiana wyraźnie ograniczyła uprawnienia TK. Może on teraz badać wegierskie ustawy jedynie w odniesieniu do procedur, a nie treści. Co więcej, uznano za niewiążące orzeczenia TK przyjęte przed wejściem w życie konstytucji w 2011 roku (Boros, 2013).

Po raz piąty konstytucja uległa nowelizacji 16 września 2014 roku. Stwierdzono, że kampania wyborcza będzie dozwolona w telewizji i radiu komercyjnym, które mogą emitować reklamy partii politycznych bezpłatnie. Poza tym wspólnoty religijne mają prawo do określania siebie jako Kościoły, ale Zgromadzenie Krajowe w dalszym ciągu ma prawo wyznaczania kościołów mających zniżki podatkowe i inne przywileje. Prezes Narodowego Urzędu Sądowego nie może przenosić spraw sądowych poza wyznaczony rejonowo do tego sąd (Comments on the Fifth Amendment to the Fundamental Law of Hungary).

Nowa konstytucja odeszła od pewnych demokratycznych standardów, które w ostatnich dziesięcioleciach wypracowały państwa Europy. Mam tu na myśli ograniczenie zakresu działania Trybunału Konstytucyjnego, ograniczenie roli parlamentu w sferze budżetowej na korzyść Rady Budżetowej, która ma prawo weta wobec budżetu, uzależnienie przekazania sprawy do innego sądu niż właściwy przez Przewodniczącego Krajowego Biura Sądownictwa od kryteriów Krajowej Rady Sądownictwa. Także tryb prac nad konstytucją oraz sposób jej uchwalenia budziły powszechny sprzeciw. Negatywny stosunek może też wywoływać treść bardzo konserwatywnej preambuły, której znaczną zawartość stanowią sformułowania natury narodowo-tradycjonalistycznej. Wskazanie 33 spraw, jako tych, które mogą być zmienione większością 2/3 głosów deputowanych pozwala rządzącemu Fideszowi zachować pewność, że uchwalone przepisy będą obowiązywać przez dłuższy czas. Należy jednak podkreślić, że w sferze formy rządów, Węgry nadal pozostają republiką, mimo że w konstytucji postanowiono zrezygnować $\mathrm{z}$ tej nazwy określając państwo po prostu jako Węgry.

\section{Podstawowe założenia nowego prawa wyborczego na Węgrzech}

Prawo wyborcze na Węgrzech jest obecnie regulowane trzema aktami. Pierwszym z nich jest konstytucja z 2011 roku, drugim ustawa CCIII o wyborze posłów do parlamentu z 2011 roku, a trzecim ustawa XXXVI z 2013 r. o procedurze wyborczej. Dwa pierwsze akty zostały przygotowane i uchwalone stosunkowo szybko przez rządzącą 
koalicję partii Fidesz i KDNP, podczas, gdy trzeci akt był kwestionowany zarówno przez prezydenta, jak i Trybunał Konstytucyjny.

Regulacje konstytucyjne dotyczące prawa wyborczego znajdują się w preambule, rozdziałach: Fundamenty, Wolność i Odpowiedzialność oraz Państwo. Suwerenem władzy jest naród, który może ją sprawować bezpośrednio lub pośrednio (art. B, pkt 1,2). Jeżeli chodzi o pośrednio sprawowaną władzę, to wykonywana jest ona przez przedstawicieli wyłanianych w wyborach. Mogą to być posłowie do Zgromadzenia Krajowego, deputowani do lokalnych ciał ustawodawczych oraz samorządowi burmistrzowie i posłowie do Parlamentu Europejskiego. W art. XXIII, pkt 1 i 2 konstytucji bierne i czynne prawo wyborcze przysługuje pełnoletniemu obywatelowi Węgier i obywatelowi kraju Unii Europejskiej, który mieszka na Węgrzech. Jednocześnie w tym samym artykule konstytucja podkreśla, że może związać czynne prawo wyborcze z miejscem zamieszkania na Węgrzech, a bierne z innymi warunkami (pkt 4). Od wyborów parlamentarnych w 2014 roku zgodnie z zapisami ustawy CCIII z 2011 roku o wyborze posłów do parlamentu prawo udziału w wyborach mają także obywatele węgierscy zamieszkujący inne kraje. Osobami pozbawionymi prawa udziału w wyborach są ci, którym sąd odebrał takie prawo w wyniku popełnienia czynu karalnego oraz osoby ograniczone umysłowo. Ponadto obywatele innych państw UE zamieszkujący Węgry nie mogą brać udziału w wyborach, jeżeli w swoim ojczystym kraju zostali pozbawieni takich praw (pkt 6). Ustawa CCIII z 2011 roku pozbawia biernego prawa wyborczego dodatkowo te osoby, które podlegają kurateli sądowej nałożonej w wyniku postępowania karnego (art. 2, pkt 3).

Wprowadzony przez nowe zapisy prawne system wyborczy zmienia dotychczasową procedurę i sposób wyłaniania deputowanych do Zgromadzenia Krajowego. Nie jest to jednak zmiana rewolucyjna, ale nie należy ona także do kosmetycznych. Nadal węgierski system ma charakter systemu mieszanego tzn. większościowo-proporcjonalnego, ale w wyniku reformy uległ on pewnemu uproszczeniu. Do tej pory obowiązywały trzy poziomy alokacji mandatów: okręgi jednomandatowe, okręgi wielomandatowe oraz lista krajowa, z której przydzielano mandaty z głosów resztkowych pozostających po podziale mandatów w jednomandatowych i wielomandatowych okręgach (Kubas, 2010, s. 123-125). W nowym systemie zmianie uległy nie tylko poziomy alokacji, ale także liczba przyznawanych mandatów. Zmniejszono liczbę okręgów jednomandatowych ze 176 do 106, natomiast liczba posłów wybieranych w okręgach wielomandatowych zmniejszyła się 152 do 93. Przy czym nie ma już list regionalnych, zastapiła je lista ogólnokrajowa. Zmieniły się też proporcje udziału mandatów z okręgów jednomandatowych i wielomandatowych. W pierwszym przypadku udział ten wzrósł z 46\% do 53\%, a w drugim z 39\% do 46\%. Nie występuje lista krajowa służąca wyłącznie rozdziałowi mandatów przy wykorzystaniu tzw. głosów resztkowych. Kolejną istotną zmianą jest ograniczenie liczby tur głosowania $\mathrm{z}$ dwóch do jednej. Termin wyborów przypada na maj, co cztery lata, a wyznacza je prezydent.

Konsekwencją tych zmian jest wzmocnienie pozycji okręgów jednomandatowych. Z jednej strony zmniejszono liczbę posłów z tych okręgów, ale z drugiej wzrosła ich rzeczywista proporcja w całkowitej liczbie mandatów w Zgromadzeniu Krajowym. Timea Drinóczi przedstawia wyniki badań, które wskazują, że przy tworzeniu nowych okręgów jednomandatowych zastosowano dwie metody ich kreacji. Pierwsza była poprawna tzn. 
opierała się ściśle o ustawowe przepisy, natomiast druga zawierała elementy manipulacji. Pierwszą metodę zastosowano tam, gdzie tradycyjnie elektorat ma charakter konserwatywny, drugą tam, gdzie przeważa elektorat lewicowy i w celu przełamania tych tendencji tak ułożono granice okręgów, aby większy był wpływ postaw prawicowych (Drinóczi, 2012, s. 55, 56).

Przywołana powyżej zasada tworzenia jednomandatowych okręgów wyborczych jest uregulowana w ustawie CCIII z 2011 roku w art. 4. Zaleca się tworzenie tych okręgów z uwzględnieniem istniejących granic podziału terytorialno-administracyjnego kraju i wewnętrznego podziału Budapesztu. Okręgi powinny składać się z obszarów przylegających do siebie, a liczba głosujących w poszczególnych okręgach winna być podobna. W przypadku, gdy liczba głosujących jest wyższa od średniej ogólnokrajowej, dopuszcza się podział miast, w tym Budapesztu, na więcej niż jeden okręg wyborczy. Dopuszcza się także zróżnicowanie liczby głosujących w okręgu powyżej 15\% od średniej krajowej, ale gdy liczba ta przekroczy 20\%, to zmiany w zakresie okręgów powinny być uchwalone mocą załącznika do istniejącej ustawy o wyborze posłów do parlamentu. Gdy w kraju dojdzie do zmian terytorialno-administracyjnych, parlament powinien zrewidować istniejący podział na okręgi wyborcze. Ustawa CCIII w załącznikach szczegółowo określa granice poszczególnych okręgów wyborczych i wskazuje ich nazwy (Act CCIII of 2011).

Każdy wyborca dysponuje zatem dwoma głosami, które oddaje w okręgu jednomandatowym oraz $\mathrm{w}$ okręgu wielomandatowym na listę zarejestrowaną na poziomie krajowym. Zmianie uległ sposób wyboru. W poprzednim systemie wyborczym w okręgach jednomandatowych wymagana była $50 \%$ frekwencja w pierwszej i $25 \%$ frekwencja w drugiej turze. Obecnie zrezygnowano z uzależnienia wyboru kandydata na posła od poziomu frekwencji. Skomplikowany sposób wyboru posła w okręgu jednomandatowym uproszczono i obecnie wystarczy uzyskać większość względną, zamiast np. bezwzględnej w poprzednim systemie. Kandydat na posła musi uzyskać co najmniej 1000 podpisów osób uprawnionych do głosowania w danym okręgu jednomandatowym. Można poprzeć tylko jednego kandydata. Poprzednio wymagano 750 podpisów. Kandydat nominowany przez partię polityczną w okręgu jednomandatowym może być umieszczony tylko na liście partii, która go popiera na poziomie krajowym.

Nowością w węgierskim systemie wyborczym jest stworzenie możliwości wyboru reprezentacji mniejszości narodowych przy zastosowaniu dodatkowych procedur. Jedna mniejszość narodowa może utworzyć jedną listę z co najmniej trzema kandydatami. Musi być poparta podpisami co najmniej $1 \%$ uprawnionych do głosowania członków danej wspólnoty narodowościowej, ale nie więcej niż 1500 podpisami. Uczestnictwo na listach mniejszości narodowej wyklucza możliwość kandydowania w okręgu jednomandatowym i z innych list narodowościowych.

Jak zostało wspomniane powyżej nie mamy już do czynienia z listami regionalnymi. Obecnie wyborcy mogą głosować na krajową listę, z której do rozdziału pozostają 93 mandaty. Na tej liście znajdować się mogą listy poszczególnych partii lub narodowości. Aby partia mogła zarejestrować swoją listę, musi wcześniej nominować kandydatów w co najmniej 27 jednomandatowych okręgach znajdujących się na obszarze co najmniej 9 komitetów i w Budapeszcie. Partie mogą tworzyć koalicje wyborcze. Ogra- 
niczono liczbę proponowanych kandydatów do trzykrotności liczby mandatów, którymi dysponuje lista krajowa. Partia może uczestniczyć w podziale mandatów po przekroczeniu 5\% uzyskanego poparcia, koalicja dwóch partii 10\% poparcia, a koalicja trzech i więcej partii $15 \%$.

Przydział mandatów dla list mniejszości narodowych opiera się na tzw. kwocie preferencyjnej, która jest liczbą całkowitą powstałą wskutek podziału głosów oddanych na listę krajową (liczbę osób, które oddały głosy w wyborach na poziomie proporcjonalnym) przez 93, a następnie przez 4. Jeżeli liczba głosów na listę mniejszości jest równa lub wyższa od kwoty preferencyjnej, wówczas mniejszość otrzymuje mandat. Jeżeli mniejszość zarejestrowała listę, a nie zdobyła mandatu to na podstawie art. 18 ustawy CCIII z 2011 roku przysługuje jej prawo wysłania do parlamentu swojego rzecznika, którym może być tylko osoba zajmująca pierwsze miejsce na liście narodowej. Mniejszość narodowa może otrzymać tylko jeden mandat preferencyjny.

Mimo zminimalizowania znaczenia głosów nadwyżkowych i nieokreślenia z góry maksymalnej ich liczby, nadal funkcjonują w systemie wyborczym. Obecnie definiuje się je jako te głosy, które pozostają niewykorzystane przez wszystkich kandydatów, którzy przegrali wybory w okręgach jednomandatowych. Ale dodatkowo głosami nadwyżkowymi są te, które powstają wskutek odjęcia od wyniku uzyskanego przez zwycięskiego kandydata wyniku drugiego kandydata plus jeden głos. Zatem każdy kandydat może obecnie wesprzeć partię, która go nominowała swoimi głosami, nawet ten, który wygrał wybory i wykorzystał już swoje głosy. 93 mandaty są rozdysponowywane dopiero po uwzględnieniu odjęcia ewentualnych mandatów preferencyjnych, które mogły zdobyć mniejszości narodowe. Obliczanie mandatów w systemie proporcjonalnym odbywa się przy uwzględnieniu metody d'Hondta. Jeżeli poseł nie może wypełniać swoich obowiązków, zastępuje go kolejny kandydat z listy z drugim największym uzyskanym poparciem. Jeżeli takowego nie było, mandat pozostaje wolny. Wybory uzupełniające mogą się odbyć, gdy w okręgu jednomandatowym nie zgłosił się żaden kandydat lub liczba uzyskanych głosów poparcia dla dwóch lub większej liczby zwycięskich kandydatów jest identyczna.

Należy wskazać, że sposób liczenia głosów nadwyżkowych zapisany w ustawie CCIII z 2011 roku nie był do tej pory znany w Europie. Niektórzy analitycy uważaja, że będzie on miał małe znaczenie w przypadku istnienia zrównoważonych sił politycznych i nie wpłynie na wynik wyborów, bo i tak zwycięska partia będzie mogła uzyskać 2/3 mandatów bez konieczności wykorzystywania głosów resztkowych. Wydaje się, że twórcy tego systemu nie zdawali sobie z tego sprawy, a za wprowadzeniem obecnej zasady głosów resztkowych przemawiała chęć wsparcia zwycięskiej partii. Niewątpliwie jednak ta metoda kompensacyjna będzie utrudniała możliwość odniesienia sukcesu wyborczego przez mniejsze partie (Drinóczi, 2012, s. 56, 57).

Nowe prawo wyborcze preferuje system dwupartyjny, a mniejsze partie mogą mieć problem z uzyskaniem mandatu, jeżeli nie będą zawierać koalicji przedwyborczych z innymi partiami. Wydaje się, że jest on korzystny dla partii Fidesz. Wiąże się to m.in. z przyznaniem prawa do głosowania Węgrom zamieszkującym kraje ościenne. Uproszczony mechanizm ułatwiający uzyskanie obywatelstwa prawdopodobnie zachęca nie tylko do jego faktycznego pozyskania, ale i uczestnictwa w wyborach parlamentarnych. A ponieważ jest to raczej elektorat o konserwatywno-narodowych poglądach, dlatego 
ocenia się, że popiera partię Fidesz. Należy przypomnieć, że Węgrzy spoza granic kraju mogą głosować tylko na listy partii (Czyż, Kubas, 2011, s. 94). Zaletą nowego systemu jest jego uproszczenie, zagwarantowanie okresu przejściowego, stworzenie możliwości wystawienia reprezentacji parlamentarnych dla mniejszości narodowych, a także dalsza klaryfikacja i stabilizacja systemu partyjnego.

Trzeci człon prawa wyborczego, czyli ustawa o procedurze wyborczej została przedstawiona jako projekt partii Fidesz i KDNP 18 września 2012 roku, a sposób w jaki wniesiono ją pod obrady przyjął formę indywidualnego wniosku. Została uchwalona w listopadzie tego samego roku. Głównym celem ustawy miała być zmiana automatycznej rejestracji wszystkich pełnoletnich obywateli Węgier posiadających pełnię praw dobrowolnym zapisywaniem się na spisy wyborców. Niespodziewanie projekt ustawy o procedurze wyborczej, mimo uchwalenia i podpisania przez przewodniczącego Zgromadzenia Narodowego w dniu 1 grudnia 2012 roku, został zawetowany przez prezydenta. W dniu 6 grudnia 2012 roku przekazał on ustawę do Trybunału Konstytucyjnego w celu zbadania kilku, jego zdaniem, niekonstytucyjnych zapisów. Należy wskazać, że prezydent nie zawetował ustawy w całości.

Prezydent wskazał na brak zasady równości w sposobie rejestracji wyborców. Wyborcy mieszkający na Węgrzech mogli dokonywać rejestracji osobiście lub w Internecie, podczas gdy wyborcy mieszkający poza granicami Węgier musieli się rejestrować listownie lub za pośrednictwem Internetu. Prezydent uważał, że bardziej restrykcyjne jest zgłaszanie się wyborców do organu władzy lokalnej niż rejestracja listowna. Poza tym zaskarżył ograniczenie kampanii wyborczej wyłącznie do mediów publicznych i zakaz prezentacji reklam politycznych w kinach. Zasada ta jest sprzeczna z zasadą wolności wypowiedzi i wolności prasy. Niedopuszczalne byłoby też zezwalanie na publikowanie sondaży tylko do 6 dnia przed wyborami, gdyż jest to sprzeczne z zasadą wolności wypowiedzi i wolności prasy. W odpowiedzi na skargę prezydenta dnia 4 stycznia 2013 roku TK stwierdził, że obowiązek rejestracji w lokalnym organie władzy niesłusznie ogranicza prawo do głosowania Węgrów zamieszkujących kraj. Natomiast sama rejestracja w niektórych przypadkach ułatwia wykonywanie praw do głosowania pewnym grupom wyborców (mniejszości narodowe oraz osoby potrzebujące pomocy, aby wziąć udział w wyborach). Jednocześnie powinno się uwzględniać rejestrację osób na podstawie adresu ich zamieszkania, a nie zameldowania. Krzywdzące jest też pozbawienie możliwości rejestracji osób nieposiadających żadnego adresu. W przypadku ograniczenia kampanii wyborczej tylko do mediów publicznych i zakazu ogłaszania sondaży opinii po 6 dniu przed wyborami TK uznał takowe przepisy za niezgodne z konstytucją (Dokument Roboczy nr 4, 2012).

Ostatecznie ustawa o procedurze wyborczej została uchwalona w kwietniu 2013 roku (Act XXXVI of 2013), a w czerwcu uległa nowelizacji. Rezygnuje ona z obowiązku rejestrowania się obywateli Węgier mieszkających w ojczyźnie na listach wyborczych w celu wzięcia udziału w wyborach. Taki obowiązek muszą natomiast spełnić Węgrzy żyjący poza granicami kraju. Ustawa nakazuje upublicznianie spisów wyborców przed wyborami. Ogranicza prawo głosowania pocztowego tylko do obywateli Wegier, którzy nie zamieszkują ojczyzny. Ponadto mogą oni wybierać tylko kandydatów umieszczonych na listach partyjnych, nie mogą dokonywać wyboru w okręgach jednomandatowych (Bozóki, 2013). 


\section{Podsumowanie}

Zwycięstwo w wyborach parlamentarnych Fidesz w 2010 roku i jej utrzymanie w 2014 roku pozwoliło tej partii na przejęcie władzy po ośmiu latach rządów socjalistów. Sukces był tym większy, że dzięki koalicji z KDNP w 2010 roku udało się uzyskać 2/3 miejsc w parlamencie. Sprzyjało to wprowadzaniu zmian w kraju bez konieczności dyskusji z opozycją. Świadomie i celowo zaczęto realizować program szeroko zakrojonych reform obejmujących zmiany w prawie. Jako pierwszą zaczęto przekształcać sferę medialną w celu uzyskania większej kontroli nad środkami masowego przekazu. Mimo protestów i odejścia od niektórych przyjętych wcześniej postanowień, nie zaprzestano reform tej sfery. Następnie przygotowywano grunt pod bardziej znaczącą zmianę, czyli uchwalenie konstytucji. Mimo tego, że nie zmienia ona w zasadniczy sposób formy państwa, to w wielu miejscach rezygnuje ze standardowych demokratycznych rozwiązań znanych w krajach Europy, przede wszystkim ogranicza rolę Trybunału Konstytucyjnego. Poza tym w warstwie wartości konstytucja ma wyraźnie konserwatywny charakter. Wprowadza aż 33 sfery, które mogą być regulowane mocą ustaw konstytucyjnych przy zachowaniu większości 2/3 głosów.

Natomiast wprowadzenie nowego prawa wyborczego ma pewne cechy doraźnego charakteru. Dzięki temu Fidesz chce zwiększyć prawdopodobieństwo odniesienia kolejnych sukcesów wyborczych. System preferuje ugrupowania duże, a okręgi jednomandatowe w pewnej mierze zostały tak wyznaczone, aby kumulować poparcie elektoratu o narodowych preferencjach sprzyjających Fideszowi. Wprowadzono możliwość głosowania Węgrów zamieszkujących poza granicami kraju, głównie w krajach ościennych. To także sprzyja prawicowemu Fideszowi. Z drugiej strony, zmiany w systemie wyborczym mają pozytywny wydźwięk. Poprzedni system mieszany przyjęty podczas rozmów trójkątnego stołu był bardzo skomplikowany. Miał 3 poziomy alokacji mandatów, obowiązywała konieczność uzyskania wysokiej frekwencji $50 \% \mathrm{w}$ okręgach jednomandatowych, co powodowało konieczność przeprowadzania dwóch tur (w drugiej turze także obowiązywała frekwencja 25\%). Stosowano dwie różne metody obliczania mandatów w drugim i trzecim poziomie alokacji. To wszystko zostało znacznie uproszczone.

Na postawione na początku artykułu pytanie należy odpowiedzieć, że zmiany zarówno podstaw ustrojowych oraz systemu wyborczego służą wzmocnieniu pozycji partii Fidesz. Zmiana konstytucji oraz innych sfer ma na celu umocnienie tradycyjnego i narodowego sposobu postrzegania spraw, co również sprzyja rządzącej partii. Sposób przeprowadzania reform znacząco odbiega od mechanizmów znanych w państwach demokratycznych. Świadczy o tym analiza ilościowa, która została dokonana przy użyciu wskaźnika demokracji (ang. democracy score) używanego przez Freedom House w raportach Nations in Transit. Uśrednia on opinie dotyczące: systemu wyborczego, społeczeństwa obywatelskiego, niezależnych mediów, rządu, sposobu demokratycznego zarządzania, samorządu terytorialnego, niezależnego sądownictwa, korupcji. Skala oceny waha się między 1 (najlepsza) do 7 (najgorsza). W ostatnim roku przed przejęciem władzy przez rząd Viktora Orbána, czyli w 2009 roku, wskaźnik wynosił 2,29, w 2012 roku wzrósł do 2,86, a w 2014 roku do 2,96, a w 2016 wyniósł 3,29. Pogorszenie notowań w zakresie konsolidacji demokracji o jeden punkt w skali siedmiocyfrowej niewątpliwie 
świadczy o tym, że reformy oddalają kraj od modernizacyjnych przekształceń, których celem jest osiągnięcie dojrzałej formy demokracji (Nations in Transit: Hungary).

\section{Bibliografia}

Act CLI of 2011 on the Constitutional Court, http://www.mkab.hu/rules/act-on-the-cc, 3.09.2014.

Act CCIII of 2011 on the Elections of Members of Parliament of Hungary, http://www.venice.coe.int/ webforms/documents/?pdf=CDL-REF\%282012\%29003-e, 28.04.2013.

Act XXXVI of 2013 on Electoral Procedure, http://valasztas.hu/en/ovi/241/241_1_10.html, 30.04.2015.

Boros T. (2013), Constitutional Amendments in Hungary: The Government's Struggle against the Constitutional Court, Friedrich Ebert Stifung, Budapest Buro, February 2013, http://www.fesbp.hu/ common/pdf/Nachrichten_aus_Ungarn_februar_2013.pdf, 17.04.2013.

Bozóki A., Access to Electoral Rights. Hungary, http://eudo-citizenship.eu/admin/?p=file\&appl=countryProfiles\&f=1319-Hungary-FRACIT.pdf, 20.05.2015.

Brodziński W. (2006), Prawo wyborcze do parlamentu Republiki Wegier, w: Prawo wyborcze do parlamentu w wybranych państwach europejskich, red. S. Grabowska, K. Składowski, Wolters Kluwer, Kraków.

Comments on the Fifth Amendment to the Fundamental Law of Hungary, http://tasz.hu/files/tasz/ imce/ngo_comments_on_the_5th_amendment_to_the_fundamental_law_october2013.pdf, 2.09.2013.

Council of Europe, Venice Comission, Documents by opinion and study: Hungary, http://www.venice. coe.int/WebForms/documents/by_opinion.aspx, 27.04.2013.

Czyż A. (2012), Legislacja jako główna funkcja parlamentów, w: Parlament w państwach Grupy Wyszehradzkiej, red. M. Barański, R. Glajcar, S. Kubas, Wydawnictwo Uniwersytetu Śląskiego - REMAR, Katowice.

Czyż A., Kubas S. (2011), Doświadczenia węgierskiej transformacji ustrojowej. Od Jánosa Kádára do Viktora Orbána, Wydawnictwo Uniwersytetu Śląskiego - REMAR, Katowice.

Dokument Roboczy nr 4 Komisji Wolności Obywatelskich, Sprawiedliwości i Spraw Wewnętrznych przy Parlamencie Europejskim z 5 marca 2013 roku w sprawie sytuacji praw podstawowych: standardy i praktyka na Wegrzech (zgodnie z rezolucją PE z dnia 16 lutego 2012 r.) - zasady demokracji i praworządności. Sprawozdawcy: Rui Tavares, Anthea McIntyre-Marie-Christine Vergiat.

Drinóczi T. (2012), Nowy węgierski system wyborczy, „Studia wyborcze”, nr (tom) 13.

Kubas S. (2012), Węgierski parlamentaryzm: od narodzin do stanu obecnego z uwzględnieniem konstytucji z 2011 r. „Przegląd Sejmowy”, nr 5 (112).

Kubas S. (2012), Wpływ węgierskiego systemu wyborczego na wyniki wyborów do Zgromadzenia Krajowego i Parlamentu Europejskiego w latach 1990-2009, „Studia Wyborcze”, nr (tom) 9.

Nations in Transit: Hungary, http://www.freedomhouse.org/report/nations-transit/2012/hungary, 17.04.2013.

Nemzeti Konzultáció: Kérdések az új alkotmányról, http://www.fidesz.hu/index.php Cikk=158885, 3.04.2013.

Rezolucja Parlamentu Europejskiego z dnia 10 marca 2011 r. w sprawie ustawy medialnej na Wegrzech (2012/C 199 E/17), http://eurlex.europa.eu/LexUriServ/LexUriServ.do?uri=OJ:C:2012:199E:0154:0157:PL:PDF, 17.05.2013.

Sokół W. (2007), Geneza i ewolucja systemów wyborczych w państwach Europy Środkowej i Wschodniej, Wydawnictwo UMCS, Lublin. 
The Constitutional Court of Hungary, Decision 45/2012, http://mkab.hu/sajto/news/certain-partsof-the-transitional-provisions-of-the-fundametal-law-held-contrary-to-the-fundamental-law, 17.04.2013.

Usawa Zasadnicza Wegier z 25 kwietnia 2011 r., http://ibr.sejm.gov.pl/tek01/txt/konst/wegry2011.html, 16.04.2013.

\title{
Changes in Electoral Law in the Context of the Transformation of the Political System in Hungary after 2011
}

\begin{abstract}
Summary
The article presents the problems of changes in the electoral law in Hungary in the light of the introduction of the new Constitution in 2011. The first part of the article discusses how the Constitution was enacted and its content. Later, the author analyzes the effects of the changes in the law and political systems.

The second part of the article focuses on the analysis of the procedure and outcomes of the changes in Hungarian electoral law after 2011. This reform was the first in the electoral field since 1990. The electoral law consists of constitutional regulations and Act CCIII of 2011 on the Elections of Members of Parliament of Hungary and Act_XXXVI of 2013 on Electoral Procedure.
\end{abstract}

Key words: Hungary, Constitution, electoral law 
